\title{
Provenance of Pleistocene Rhine River Middle Terrace sands between the Swiss-German border and Cologne based on U-Pb detrital zircon ages
}

\author{
Anne Krippner $\cdot$ Heinrich Bahlburg
}

Received: 24 January 2012/Accepted: 31 October 2012/Published online: 27 December 2012

(C) Springer-Verlag Berlin Heidelberg 2012

\begin{abstract}
Detrital zircon U-Pb age distributions derived from samples representing ancient or relatively young large-scale continental drainage networks are commonly taken to reflect the geochronological evolution of the tapped continental area. Here, we present detrital zircon $\mathrm{U}-\mathrm{Pb}$ ages and associated heavy mineral data from Pleistocene Rhine River Middle Terrace sands and equivalents between the Swiss-German border and Cologne in order to test the commonly assumed Alpine provenance of the material. Samples from eight localities were analyzed for their heavy mineral assemblages. Detrital zircon $\mathrm{U}-\mathrm{Pb}$ ages were determined by laser ablation inductively coupled mass spectrometry on selected samples from five locations along the Rhine River. The zircon age populations of all samples show a similar distribution, their main peaks being between 300 and $500 \mathrm{Ma}$. Minor age populations are recognized at 570 and 1,070 Ma. The 300-400 Ma maximum reflects the Variscan basement drained by or recycled into the Rhine River and its tributaries. The 400-500 Ma peak with predominantly Early Silurian ages points to Baltica or to the mid-German crystalline rise as original sources. One distinct peak at c. $570 \mathrm{Ma}$ probably represents input from
\end{abstract}

Electronic supplementary material The online version of this article (doi:10.1007/s00531-012-0842-8) contains supplementary material, which is available to authorized users.

A. Krippner · H. Bahlburg

Institut für Geologie und Paläontologie,

Westfälische Wilhelms-Universität Münster,

Corrensstrasse 24, 48149 Münster, Germany

\footnotetext{
A. Krippner ( $\square)$

Department of Sedimentology and Environmental Geology,

Göttingen University, Goldschmidtstraße 1-3,

37077 Göttingen, Germany

e-mail: Anne.Krippner@geo.uni-goettingen.de
}

Cadomian terranes. The Precambrian U-Pb ages are compatible with derivation from sources in Baltica and in northern Gondwana. The heavy mineral populations of Middle Terrace sands and equivalents are characterized to a variable extend by garnet, epidote, and green hornblende. This association is often referred to as the Alpine spectrum and is considered to be indicative of an Alpine provenance. However, hornblende, epidote, and garnet are dominant heavy minerals of collisional orogens in general and may also be derived from Variscan and Caledonian units or from intermittent storage units. A remarkable feature of the detrital zircon age distribution in the Rhine River sediments from the Swiss-German border to Cologne is the absence of ages younger than $200 \mathrm{Ma}$ and in particular of any ages reflecting the Alpine orogeny between c. 100 and $35 \mathrm{Ma}$. Sediments from rivers draining the equally collisional Himalaya orogen contain detrital zircons as young as $20 \mathrm{Ma}$. Our results question the assumption that Pleistocene Rhine River sediments were directly derived from the Alps. The lag time between the formation and deposition age of the youngest zircon in the studied Pleistocene Rhine River deposits is $200 \mathrm{Ma}$. Together with the absence of Alpine zircon ages, this stresses that detrital zircon age data from ancient sedimentary units found in poorly understood tectonic or paleogeographic settings need to be interpreted with great care, one could miss an entire orogenic cycle.

Keywords Provenance - Heavy minerals - Detrital zircon . $\mathrm{U}-\mathrm{Pb}$ dating $\cdot$ Rhine River $\cdot$ Alps

\section{Introduction}

Heavy minerals are very useful indicators of the provenance of siliciclastic sediments and sedimentary rocks 
(e.g., Morton 1991; Garzanti and Andò 2007a, b). Due to specific mineral assemblages, they provide crucial information on the provenance from a variety of orogenic and other sources (Garzanti and Andò 2007a, b; Garzanti et al. 2007). Ideally, the heavy mineral assemblage in sediments reflects their parent rock association. However, the heavy mineral composition is affected by several critical processes operating during a sedimentary cycle, for example weathering in the source area, abrasion, hydrodynamic sorting during transport and deposition, weathering during alluvial storage on flood plains, and diagenesis (Morton and Hallsworth 1999). Consequently, different compositions of heavy mineral assemblages do not necessarily hint at different sources, but may reflect synsedimentary and diagenetic modifications which need to be considered carefully (e.g., Morton and Hallsworth 1999, 2007).

The heavy mineral zircon is a particular useful mineral in provenance research because of its chemical and mechanical stability, its presence in siliciclastic sedimentary rocks, and its capacity to act as a reliable $\mathrm{U}-\mathrm{Pb}$ geochronometer (Harley and Kelly 2007). The increased availability and reliability of LA-ICP-MS U-Pb ages of detrital zircons (e.g., Kosler and Sylvester 2003; Chang et al. 2006) offers the possibility to analyze the geochronological evolution of source terranes and the relationship between sources and sinks of sediment. Detrital zircon ages have been successful in discriminating between different source regions and sediment delivery pathways (e.g., Sircombe 1999; Augustsson et al. 2006; Bahlburg et al. 2010). The presence of a given zircon age population and similarities in age distributions is taken as evidence of a common provenance (e.g., Cawood et al. 2003, 2007; Bahlburg et al. 2010; Gehrels 2011; Linnemann et al. 2007).

Source-sink relationships may be obscured in ancient sedimentary systems as source regions may be eroded leaving the sedimentary rocks as the only and somewhat isolated evidence of the original paleotectonic and paleogeographic setting. The completeness of the preserved geochronological record of a source region depends to a large part on the drainage area supplying sediment to the sink. Small rivers tapping limited drainage systems likely present only a partial record of the larger source area. Large, potentially continental-scale river systems like the Mississippi of North America or the Rhine River systems in Europe, in turn, are considered to reflect the continentwide crustal record (e.g., Rino et al. 2008; Bahlburg et al. 2009; Condie et al. 2009). A similar, homogenized signal may be expected from marine sediments after redeposition and mixing.

When analyzing the detrital zircon record of ancient sedimentary rocks, it is generally assumed that the obtained age data qualitatively, if not quantitatively, reflect the complete geochronological record of the larger source area.
In order to test this assumption, we analyzed the detrital zircon age record and associated heavy mineral composition of Pleistocene Middle Terrace sediments of the Rhine River along the river's course from Freiburg in the south of Germany near the French and Swiss borders to a point north of the city of Cologne. From the river's headwaters in the Cenozoic Alps, the Rhine traverses several Variscan basement units, receives detritus from its tributaries draining large areas covered by Mesozoic sedimentary rocks, taps the products of the Cenozoic Eifel volcanic field, and finally enters the modern coastal plain (Fig. 1).

This ample drainage system should ensure that a complete detrital zircon age record of the geochronological evolution of the Central European crust is contained in the Rhine River sediments. Several studies analyzed heavy minerals in the Rhine River sediments using their optical characteristics only (e.g., Van Andel 1950; Hagedorn 2004). There are no single-grain geochemical data on heavy minerals either of the Rhine River itself or of its tributaries. Geochronlogical data are hitherto only available from a restricted study by Schärer et al. (2012) who obtained between 15 and 33 detrital zircon $\mathrm{U}-\mathrm{Pb}$ ages from four samples of Miocene, Pliocene, Pleistocene, and Holocene sediments of the Lower Rhine Basin. Here, we present $\mathrm{U}-\mathrm{Pb}$ detrital zircon ages of the Late Pleistocene Rhine River covering the river between the Swiss-German border and Cologne. We analyzed the age spectra of five samples comprising between 76 and 174 age dates. We use our data to test the assumption that the detritus constituting the Pleistocene sediments of the Rhine River is derived mainly from the Alps. However, our detrital zircon age results demonstrate that this assumption is not entirely confirmed. We also address a general problem concerning the interpretation of detrital zircon age data of ancient successions. If a drainage area is sufficiently large, such data on ancient rocks are commonly considered to represent the entire geochronological structure of the wider source region. In view of the good knowledge of the geological evolution and geochronological structure of the European continent, we will test to which degree the geochronological structure of Europe is in fact reflected in our age data.

\section{Geological setting and provenance of Pliocene-Pleistocene Rhine River sediments}

Since the Late Pliocene and the Early Pleistocene, the Rhine River acted as the only drainage system that connected the Alps with northern Europe and the North Sea (Gabriel et al. 2008). The Rhine River originates in the Central Alps of Switzerland. From the river's headwaters in the Alps, the Rhine traverses the Variscan basement 
Fig. 1 Simplified map of the Rhine River drainage system of central Europe (modified from Bernet et al. 2004). Sample localities: 1 Hartheim,

2 Nambsheim, 3 Heidelberg

Uni-Nord, 4 Pfungstadt-Hahn,

5 Mülheim-Kärlich,

6 Ariendorf, 7 Brühl,

8 Köln-Widdersdorf

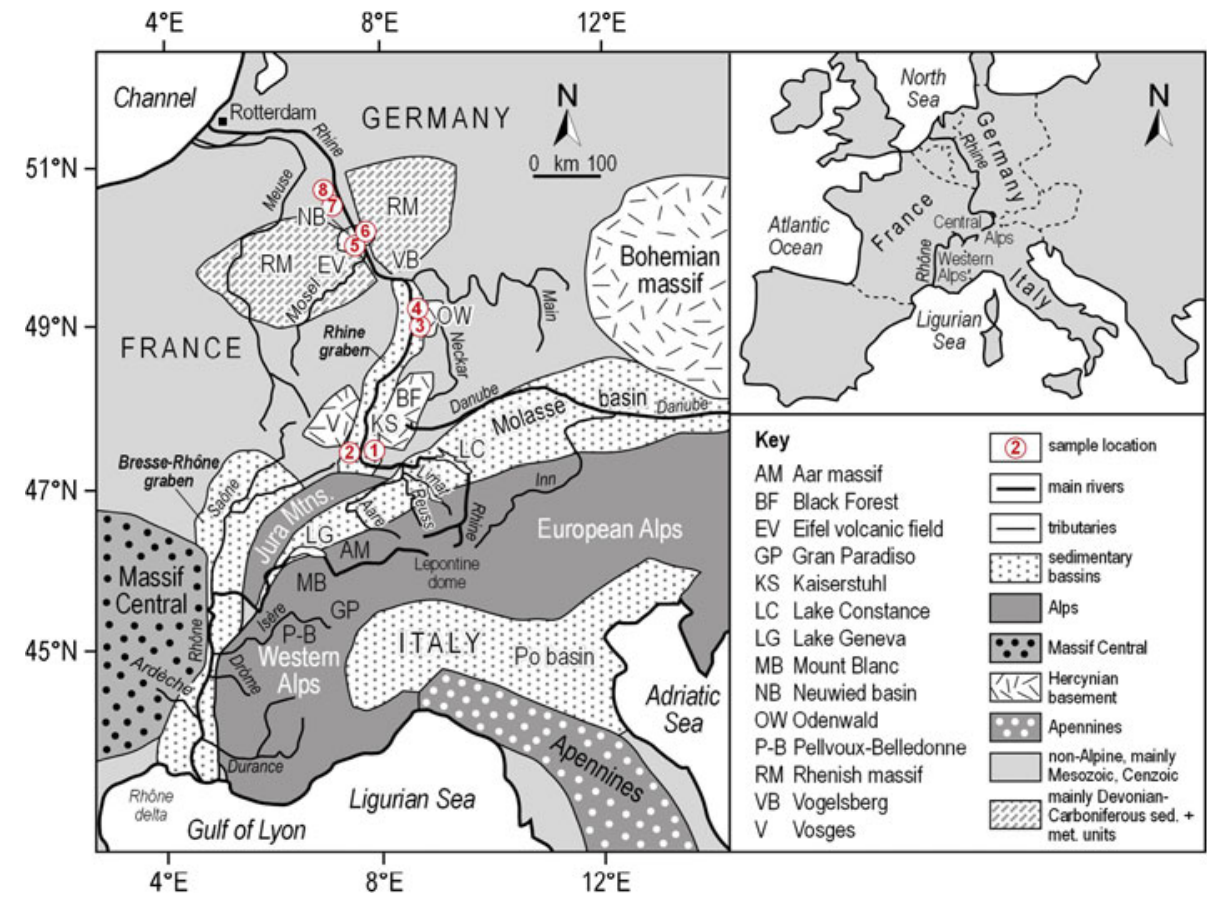

outcrops of the Black Forest and Vosges, tributaries drain large areas of southern Germany and eastern France covered by Mesozoic sedimentary rocks, traverses the Variscan Rhenish Slate Mountains where large volumes of Paleozoic sedimentary rocks and the products of the Quaternary Eifel volcanic field (215-11 ka) are exposed, and finally continues on the northwest German and Dutch coastal plain (Fig. 1).

The Alpine part of the Rhine River (Alpine Rhine) has its origin in canton Graubünden, situated in the southeastern part of Switzerland in the central Alps and is bordering Italy, Austria, and Liechtenstein (Fig. 1). The socalled Vorderrhine and Hinterrhine Rivers are the two headwaters which combine in the Alpine Rhine flowing into Lake Constance. The Alpine Rhine drainage system makes up only $4 \%$ of the total Rhine drainage network (Allen 1997; Bernet et al. 2004). Downstream of Lake Constance, the Rhine River is fed from the south by three main tributaries, the Limat, Reuss, and Aare Rivers (Fig. 1).

The complex European geology is a result of repeated collisions between Gondwana, Laurentia, Baltica, and numerous peri-Gondwanan terranes interchanging with phases of continental extension (e.g., Nance et al. 2010; Stampfli et al. 2002; Ziegler and Dèzes 2006). At the end of the Neoproterozoic and during the Early Cambrian, periGondwanan terranes drifted toward the north, either as separate entities or as parts of Africa (Robardet 2003; Tait et al. 1997; Linnemann et al. 2004, 2007) and were reassembled during the Caledonian and Variscan orogenies (e.g., Kroner et al. 2007; Krawczyk et al. 2008; Nance et al.
2010; Zeh and Gerdes 2010). In the Early Middle Jurassic, major rifting phases led to the formation of continental rift zones and the opening of the Alpine Tethys and the North Sea (Ziegler and Dèzes 2006; Robertson 2007). The development of the Alps is a result of closure of the Tethys between Africa and Europe (Pfiffner 1992; Schmid et al. 2008; Stampfli and Hochard 2009). The collisional Alpine orogen is characterized by highly complex nappe structures exposing a wide spectrum of Phanerozoic lithological units ranging from unmetamorphosed to high metamorphic grade (e.g., Trümpy 1975; Pfiffner 1992; Schmid et al. 2008). During the Pleistocene, the Eifel hotspot led to volcanism and the deposition of related tephra in the Middle and Lower Rhine valley (Bogaard and Schmincke 1990; Boenigk and Frechen 2006).

The Middle Terraces of the Rhine River

The sands pertaining to the Middle Terraces and equivalents of the Rhine River system were deposited in the Upper Middle Pleistocene between c. 550 and $250 \mathrm{ka}$ (Boenigk and Frechen 2006). The Middle Pleistocene ranges between 780 and $126 \mathrm{ka}$. This period corresponds to marine isotope stages (MIS) 15-6 (Cohen and Gibbard 2011) and post-dates the Middle Pleistocene Event of major valley downcutting along the northern Alps at c. $870 \mathrm{ka}$ (Muttoni et al. 2003; Litt et al. 2008). Regarding the Alpine glacial chronology, the Middle Terrace and equivalent sediments interfinger with the succession of ice advances and retreats during the most extensive glaciation (Möhlin Glaciation) in Switzerland represented by the 
Hosskirch Glaciation in Baden-Württemberg and the Koblenz (CH) or Riss Glaciation (D). In NW Europe, this succession of events corresponds to the Upper Cromerian Complex, the Elsterian ice advance, and the Holsteinian interglacial (Litt et al. 2008). The studied sediments were furthermore deposited prior to the onset of the main volcanic activity in the Eifel volcanic field (Litt et al. 2008) but may have received detritus from the erosion of older volcanic centers.

Crucial arguments for selecting the Middle Terraces for our study were given by (1) the case that at this time, the major rivers originating in the northern Central Alps had already combined with the Rhine River, and (2) that the Middle Terrace deposits predate the glacier movementinduced formation by overdeepening of the major lake basins of lakes Constance, Zurich, Vierwaldstätt, and others (Handtke 1980; Hsü et al. 1984). If these had been present already in the Middle Pleistocene, they could have acted as traps for sediment delivered to the Rhine River by the Alpine Rhine Rivers, the Aare, Reuss, Limat, and Thur (Villinger 1998). Given present accumulation rates, however, Lake Constance will be filled with sediment within $22 \mathrm{ka}$ (Bernet et al. 2004) and would thus represent only an ephemeral trap.

Middle terrace sands in the Upper Rhine Graben were sampled from four cores from $\mathrm{S}$ to $\mathrm{N}$ at Nambsheim, Hartheim, Heidelberg "UniNord," and Pfungstadt-Hahn (Fig. 1). The southernmost samples were obtained from the cored boreholes of Hartheim and Nambsheim of the Interegg II drilling project. The borehole at Hartheim is located on German territory, c. $2.3 \mathrm{~km}$ northeast of Hartheim near the eastern bank of the Rhine River. The borehole of Nambsheim is located on French territory, c. $1 \mathrm{~km}$ northeast of Nambsheim. Nambsheim and Hartheim represent the upper Rhine valley between the Variscan basement highs of the Black Forest and Vosges.

Heidelberg Uni-Nord and Pfungstadt-Hahn are near the crystalline basement of the Odenwald and in reach of input from the Neckar River draining the Mesozoic cover rocks exposed extensively in the Land of Baden-Württemberg (Fig. 1). The borehole of Pfungstadt-Hahn is located in the central Hessian part of the northern Upper Rhine Graben.

In the middle Rhine area, river sands of Mülheim-Kärlich, located near Koblenz between the rivers Rhine, Moselle, and Nette (samples MK1, MK3) and Ariendorf, located between Bonn and Koblenz (samples A1, A3) were collected (Fig. 1). The Mülheim-Kärlich and Ariendorf sandpits are located in the Neuwied Basin, a Cenozoic and Quaternary basin structure within the extensively exposed Paleozoic sedimentary rocks of the Rhenish Massif. In the Lower Rhine embayment, Middle Terrace sands near Brühl, located between Cologne and Bonn (Fig. 1, samples BR1, BR3) and at Köln-Widdersdorf, located northwest of
Cologne (Fig. 1, samples KW1, KW3) were sampled. The Brühl and Köln-Widdersdorf sandpits are located north of the northern terminus of the Rhenish Massif (Fig. 1).

\section{Methods}

After sieving the samples to fine sand particles, the $<250 \mu \mathrm{m}$ fractions were washed and cleaned. All grain sizes below $250 \mu \mathrm{m}$ are considered. Organic substances were removed. After drying, the samples were magnetically separated manually.

Heavy mineral analysis

The heavy mineral fraction $<250 \mu \mathrm{m}$ was separated using LST (fast float) with a density of $2.8 \pm 0.02 \mathrm{~g} / \mathrm{mL}$. The heavy mineral residues were mounted on microscope slides (Mange and Maurer 1992) and were identified under the polarizing microscope. To determine the relative abundances of the heavy minerals, they were point counted under the polarizing microscope. For this procedure, the microscope slide is moved by a mechanical stage and the grains, which are intersected by the crosshair, are identified and counted (Mange and Maurer 1992). Point counting of 500 grains/sample determined the quantitative composition of the heavy mineral spectra. In a first table, all grains were considered including micas, carbonates, and opaque minerals, which have not been removed by magnetic separation (sa1). In another table, only transparent minerals are considered (sa2).

\section{U-Pb LA-ICP-MS geochronology}

Zircons were $\mathrm{U}-\mathrm{Pb}$ dated by laser ablation inductively coupled mass spectrometry (LA-ICP-MS) at the Institut für Mineralogie, Münster University. The analytical setup and procedure uses a New Wave UP 193HE ArF Excimer laser ablation system in conjunction with a Thermo-Finnigan Element2 ICP-MS. The evaluation of the data has been carried out using Isoplot/Ex software (K. Ludwig, Berkeley Geochronology Center, CA, USA). Before using the heavy mineral liquid solution, the $<250 \mu \mathrm{m}$ fractions were magnetically separated using Frantz Isodynamic ${ }^{\circledR}$ Magnetic Separator Model L-1 and subsequently purified again by magnetic separation. Final selection of the zircons was achieved by handpicking under a binocular microscope. Zircons from several samples of one location were combined in one composite sample. We randomly selected every zircon grain in the samples of all sizes and morphological types and set them in synthetic mounts. Zircon rims were preferentially analyzed to date the last growth state of each zircon. The spot size was either 30 or $25 \mu \mathrm{m}$, 
depending on the size of the grain. The GJ-1 standard $(608.5 \pm 0.4 \mathrm{Ma}$, Jackson et al. 2004) was regularly analyzed after every 10th zircon analysis and used for internal correction of the obtained sample ratios and error calculation. In addition, we periodically analyzed the 91500 zircon standard with an age of 1,065 $\pm 0.6 \mathrm{Ma}$ (Wiedenbeck et al. 1995) as an unknown. The interpreted ages are based on ${ }^{206} \mathrm{~Pb} /{ }^{238} \mathrm{U}$ ratio for grains younger than $1,000 \mathrm{Ma}$ and ${ }^{206} \mathrm{~Pb} /{ }^{207} \mathrm{~Pb}$ ratio for grains older than $1,000 \mathrm{Ma}$ (Nemchin and Cawood 2005). Grains with a discordance $>10 \%$ were excluded from further consideration. Internal zoning of the zircons was observed by cathode luminescence using a JEOL 840 Scanning electron microscope at the University of Münster. The microscope has a conventional SE and BSE-and a Centaurus-BSE/CL-detector system, equipped with an OXFORD INCA EDX-system. The acquisition was then transferred through analySISsoftware. The zoning pattern was used to distinguish between unzoned or sector zoned metamorphic and igneous grains characterized by concentric oscillatory zoning under cathode luminescence (Vavra 1990; Vavra et al. 1999).

\section{Results}

Heavy mineral analysis

Along the Rhine River, the principal heavy minerals are garnet, epidote, and green hornblende. They represent between 30 and $90 \%$ of the transparent heavy mineral spectra (Fig. 2). Apatite and brown hornblende also occur in all samples with up to c. $15 \%$. Pyroxene occurs in small amounts in the upper Rhine valley and becomes very prominent in the middle and lower Rhine area, reaching almost $40 \%$ of the entire spectrum near Cologne (Fig. 2). The group of minerals including monazite, spinel, and sphene, here grouped as "others," is more abundant in the northern part of the river. The proportion of stable heavy minerals zircon, tourmaline, and rutile is generally low (Fig. 2). Staurolite, sillimanite, and disthene with a characteristic metamorphic provenance are grouped here as "metamorphic minerals" and commonly occur in singledigit percentages (Fig. 2). Tables of groups of heavy mineral assemblages are included in the supplementary appendix (sa3). Carbonate grains can be abundant (up to $35 \%$ ) in the south and are absent from the northern samples (sa1). Some minerals cannot be identified unequivocally. They are grouped as alterites (Van Andel 1950; Hagedorn 2004) and may make up $20 \%$ of the spectra (sa1). They probably originated by the alteration of various minerals and are aggregates with no well-defined mineralogical composition (Van Andel 1950). Carbonate, alterites, and micas are not included in Fig. 2. Here, only transparent minerals are considered to get the true information of the total concentration of transparent minerals.

\section{$\mathrm{U}-\mathrm{Pb}$ dating of detrital zircons}

Six-hundred and forty zircon grains from five locations along the Rhine River were dated. Tables of La-ICP-MS $\mathrm{U}-\mathrm{Pb}$ zircon results are included in the supplementary appendix (sa4). Most of the zircons show concentric oscillatory zoning under cathode luminescence, usually indicating an igneous origin (Vavra 1990; Vavra et al. 1999; Fig. 3). Some of the zircons are unzoned or show sector zoning, which indicate a metamorphic origin (Vavra 1990; Vavra et al. 1999). Metamorphic grains make up $<10 \%$ of each sample.

The detrital zircon $\mathrm{U}-\mathrm{Pb}$ ages range between $3,083 \pm 33$ and $201 \pm 10 \mathrm{Ma}$. The ages from all samples show very similar distributions and abundances with a broad concentration of ages between ca. 300 and $500 \mathrm{Ma}$ (between 47 and $71 \%$ of ages; Fig. 4; Tab. sa4). Within this age bracket, two broad peaks occur. The older maximum extends from about 500 to $400 \mathrm{Ma}$ (between 17 and $50 \%$ of ages) with the main peaks between 470 and $430 \mathrm{Ma}$ and an average peak value at c. $440 \mathrm{Ma}$ (Figs. 4, 5). The younger age cluster is between 400 and $300 \mathrm{Ma}$ (between 21 and $37 \%$ of ages); main peaks are at 350-300 Ma with an average peak value at c. $350 \mathrm{Ma}$ (Figs. 4, 5). For grains older than $500 \mathrm{Ma}$, a minor peak is at c. $570 \mathrm{Ma}$. Except for one grain in the Pfungstadt sample, the patterns do not show Archean ages. A particularly noteworthy feature of the age patterns is the absence of grains younger than $200 \mathrm{Ma}$ and particularly of ages reflecting the Alpine orogeny between c. 100 and $35 \mathrm{Ma}$ and subsequent tectonic processes (Froitzheim et al. 2008).

\section{Derivation of the detritus}

\section{Heavy minerals}

The principal heavy minerals in our samples and in the Rhine River sediments in general are garnet, epidote, and green hornblende (Fig. 2). These minerals are commonly grouped as the Alpine spectrum (Van Andel 1950; Boenigk 1987; Hagedorn 2004). But this mineral assemblage is not only found in collisional orogens such as the Alps. Hornblende, garnet, and epidote are diagnostic minerals of collisional orogens in general (Garzanti et al. 2007), including ancient orogens such as the Caledonian or Variscan orogens, the rocks of which make up large areas of the European continent (Kroner et al. 2008). Thus, the term A. spectrum may not be well chosen here. 
Fig. 2 Transparent heavy mineral spectra of the sampled sands at localities:

FR1 Hartheim,

FR2 Nambsheim,

$H D$ Heidelberg Uni-Nord, $P F$ Pfungstadt, $M K$ MülheimKärlich, A Ariendorf, $B R$ Brühl, $K W$ Köln-Widdersdorf. Stable minerals: zircon, rutile, tourmaline; metamorphic minerals: staurolite, sillimanite, kyanite; others: monazite, sphene, spinel

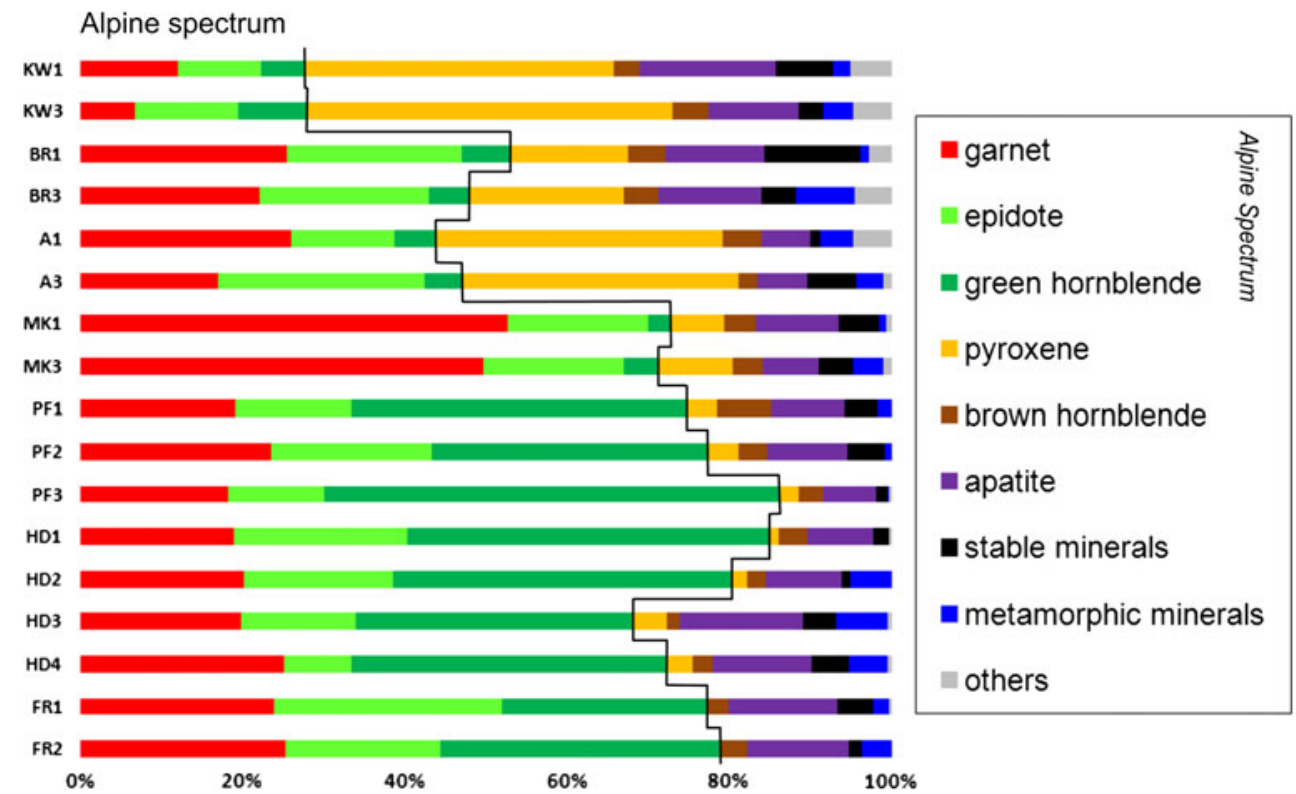

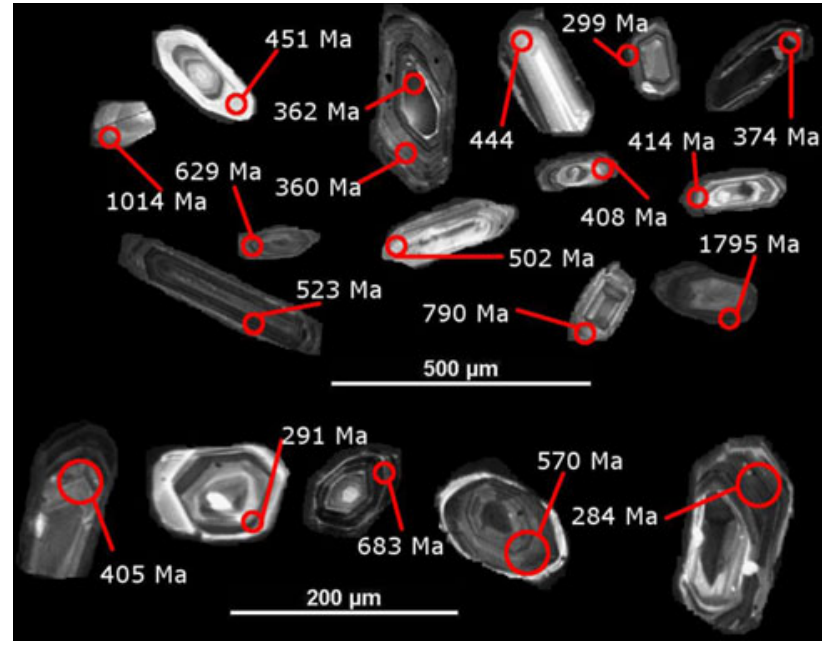

Fig. 3 Cathode luminescence images and $\mathrm{U}-\mathrm{Pb}$ ages of zircons of the Rhine River. The scale refers to the zircons above it

Garnet most commonly derives from metamorphic rocks, especially from medium-grade metapelites, but can also be of plutonic origin. Epidote is typical of low-grade metabasites but may also be common in altered granitoid rocks. Green hornblende is common in igneous and metaigneous rocks and in amphibolite-grade metamorphic rocks (Garzanti and Andò 2007a).

Throughout the whole upper Rhine province, the heavy mineral association remains essentially the same. An important tributary is the Aare River (Fig. 1). Sands from the Aare River are enriched with altered minerals, garnet, epidote and contain only minor green hornblende (Van Andel 1950). Rivers draining the central and southern Black Forest carry a noticeable percentage of green hornblende. Crystalline rocks of the Vosges contain brown and green hornblende (Hagedorn 2004). Garnet, hornblende, and epidote have been derived either from the Alps, or from the Black Forest and Vosges. Pyroxene was probably derived from the nearby Kaiserstuhl. The small percentages of sillimanite could be sourced by sillimanite-bearing gneisses of the Vosges, mainly from sillimanite gneisses of the Monotonous group, which make up the main part of this group (Latouche et al. 1992), or from respective rocks in the Alps (Van Andel 1950; Hagedorn 2004). In addition, some gneisses of the southern Black Forest carry some percentages of sillimanite (Hincke 2010); especially the Hauensteiner Murgtal gneisses which are widely distributed in the southern and southeastern parts of the Black Forest Granite and Gneiss Complex contains significant amounts of sillimanite (Kroner et al. 2008). Staurolite grains are commonly found in medium-grade regional metamorphic rocks, for example mica shists. Staurolite is known from rocks of the Bohemian Massif mainly from garnet micashists of the Moravikum (Höck et al. 1990; Von Hooshang 1993) and from glass sands from the Oligocene Molasse of southern Germany (Mange and Maurer 1992). Staurolite is a main component of the Melker Sande delivered by sediments of the Bohemian Massif (Roetzel and Kurzweil 1968). The influence of the Buntsandstein Odenwald (OW, Fig. 1) with predominantly stable minerals (Van Andel 1950) is small. Generally, the ZTR index (Hubert 1962) of the upper Rhine valley deposits is low $(\mathrm{ZTR}=1.2-7 \%)$.

Sediments from the middle and lower Rhine valley are characterized by a high pyroxene, epidote, and garnet content. Remarkable is the high garnet content in the river sands of Mülheim-Kärlich. Garnet grains are likely delivered by the Moselle River, which carries angular garnet 
Fig. 4 LA-ICP-MS U-Pb ages (black) with probability curves. On the right side details of $\mathrm{U}-\mathrm{Pb}$ ages histogram distribution of analyzed zircons (black) with grey probability curves
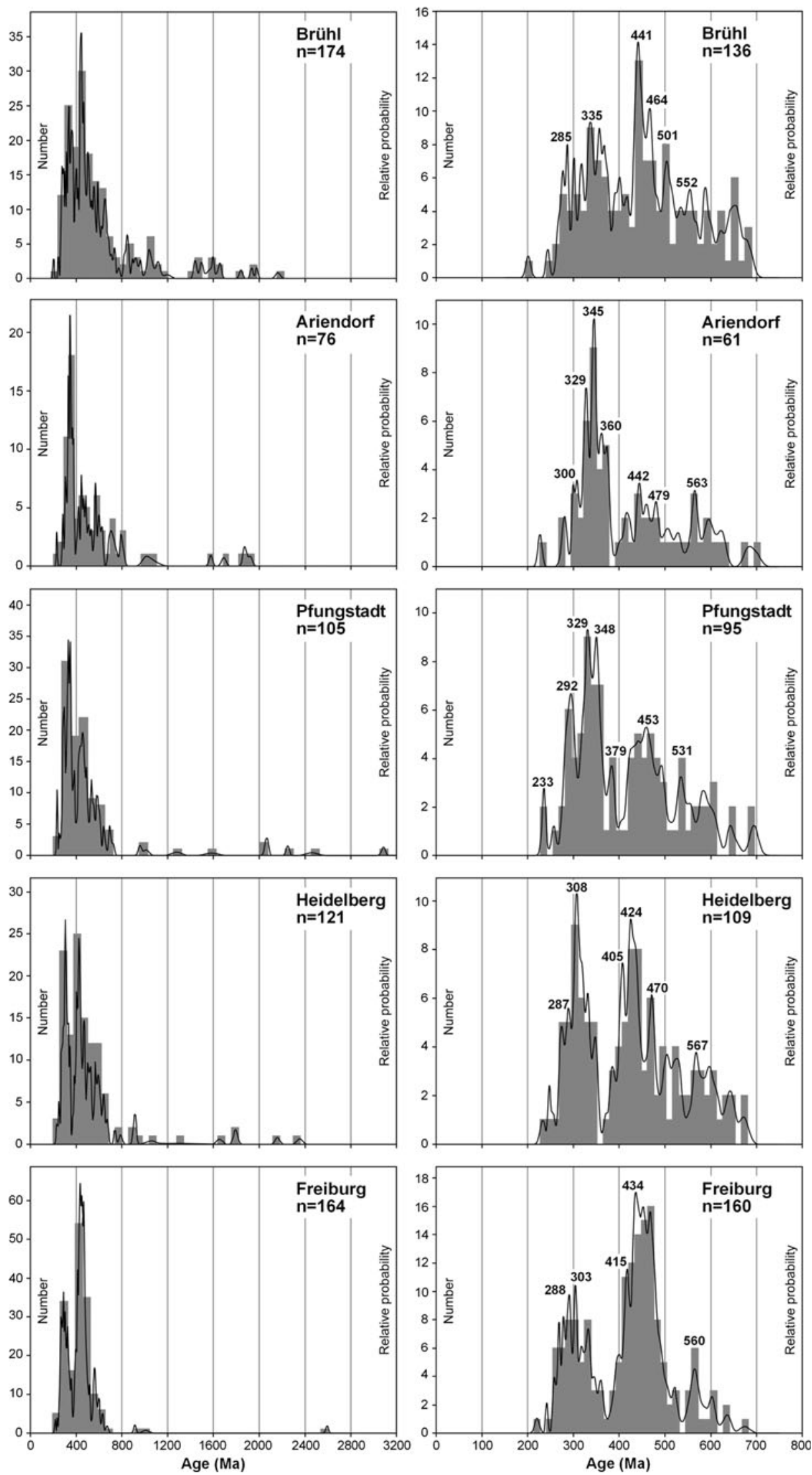


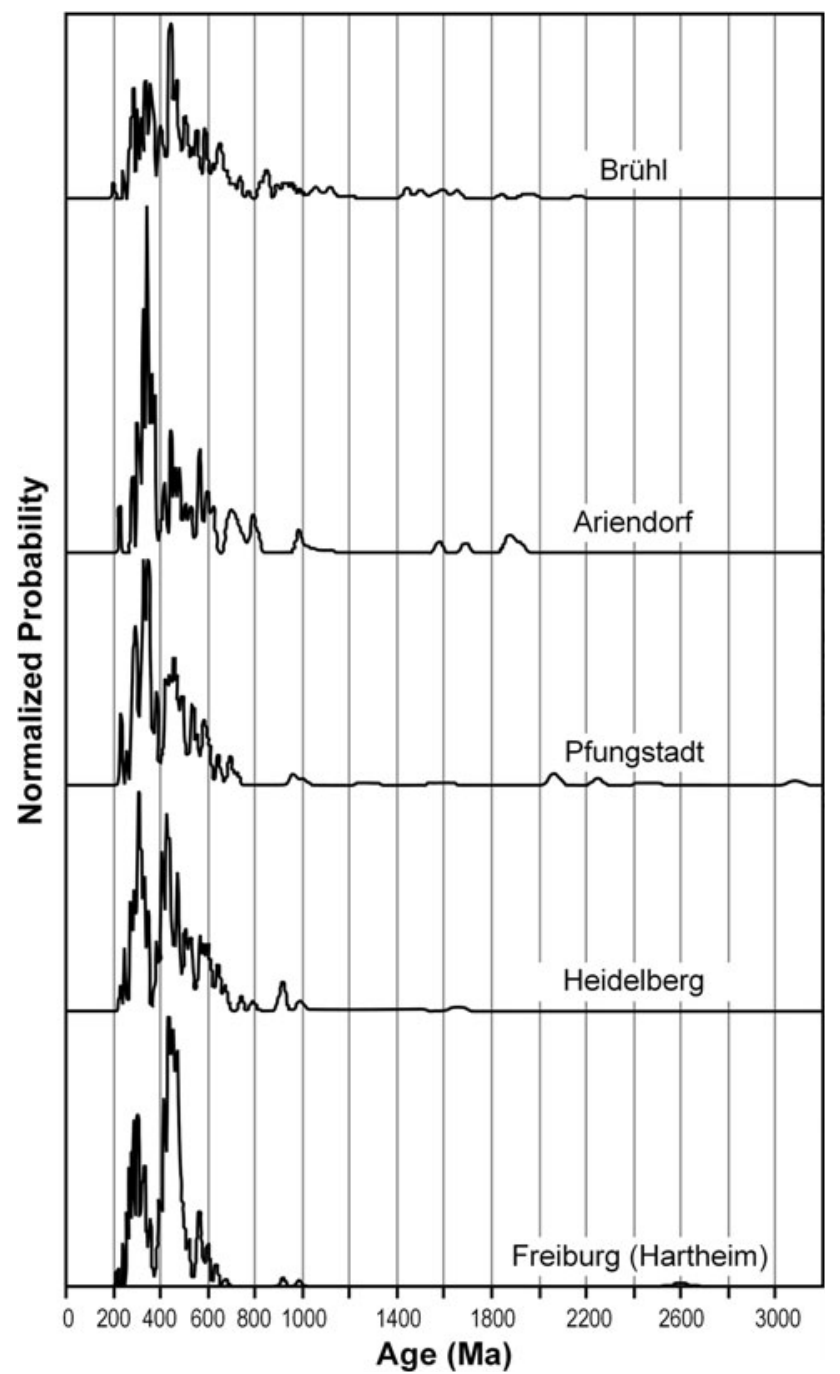

Fig. 5 Normalized probability plot (Gehrels 2000) for U-Pb age distributions of all 5 studied samples. Samples are arranged from $\mathrm{S}$ to $\mathrm{N}$ from bottom to top of the figure

from the crystalline rocks of the Vosges (Van Andel 1950). The high garnet content could also be a result of hydrodynamic conditions. Garnet is slightly denser than epidote and green hornblende. Therefore, a preferential concentration of garnet grains is possible and could bias the provenance signal. Through hydraulic processes, grains are segregated according to their size, density, and shape. Enrichment of specific minerals also depends on the selected grain size window (Garzanti et al. 2009). In our study, we use a broader size range to minimize the bias in our data.

Some sediments of the Middle Terraces of the middle Rhine valley in the Rhenish Slate Mountains are dominated by basaltic hornblende, some by pyroxene (Boenigk and Frechen 2006). The dominating mineral in our samples from this region is pyroxene (Fig. 2). Both basaltic hornblende and pyroxene are probably derived from Early
Pleistocene and Neogene volcanic centers in the Eifel area (Boenigk and Frechen 2006). In this context, it is interesting to mention Blatt (1978), who showed that in sediments covering the entire Vogelsberg area, a very rapid decrease in volcanic fragments from the percentage of 50 to $<5 \%$ occurs within $5 \mathrm{~km}$ of the basalt/Buntsandstein contact. This is interpreted to be due to the fact that streams on the plains surrounding the volcanic highlands contain no terrace gravels, which would be suitable intermittent storages and sources of the eroded volcanic material. However, the noticeable percentage of pyroxene in our Rhine River samples demonstrates that the dilution effect described by Blatt (1978) did not significantly operate in the transfer of material from the Eifel volcanic centers to the Rhine River. Zircon, tourmaline, and rutile may have been recycled from widely exposed Paleozoic sedimentary rocks (Sindowsky 1936; Van Andel 1950). The populations of these heavy minerals are not prominent and are very likely overwhelmed by the voluminous input from locally derived volcanic pyroxene and from other unstable minerals derived from the south. In addition to the mentioned garnets, the Moselle River delivers hornblende from the crystalline rocks from the Vosges together with minerals from the Keuper and the Buntsandstein (Van Andel 1950). Green hornblende also occurs in every sample. Stable mineral populations derived from Triassic sedimentary rocks (Van Andel 1950) have no significant impact on the heavy mineral spectrum in the middle and lower Rhine valley, as already demonstrated also for the Upper Rhine area. The ZTR index (Hubert 1962) of the lower Rhine valley deposits is $3-11.8 \%$ (sa2).

It is interesting to note that mid-Cenozoic sediments of the Swiss Molasse basin are also characterized by the $A$. spectrum of heavy minerals and are interpreted to have been sourced from the exhuming Alpine regions (Spiegel et al. 2002; von Eynatten 2007). The heavy mineral composition of the Middle Terrace sands and particularly the abundance of garnet, epidote, and green hornblende are in accordance with the commonly inferred provenance from the Alps. However, grains may also have been derived from the Black Forest and Vosges (Hoselmann 2008), or may have been recycled from older Cenozoic Molasse basin sediments.

\section{$U-P b$ zircon ages}

The samples from all five Middle Terrace sites have relatively uniform zircon age distributions bracketed between c. 3,100 and $200 \mathrm{Ma}$ (Figs. 4, 5). The similarity of the age distributions (Gehrels 2000) is relatively high with similarity values between 0.74 and 0.86 (Fig. 6b). A perfect similarity would have a value of 1.0. The degree of overlap of the determined age probabilities, that is, the degree to 
Fig. 6 a Cumulative

probability plot (Gehrels 2000)

of $\mathrm{U}-\mathrm{Pb}$ age distributions of all

5 studied samples; b statistical

parameters of overlap and

similarity. Overlap is the degree

to which age probabilities

overlap; 1.0 is perfect overlap,

0.0 is no overlap. Degree of

similarity is a measure of

whether propotions of

overlapping ages are similar.

Higher values (up to 1.0) reflect

similar proportions of

overlapping ages. Lower values

(down to 0.0) reflect different

proportions of ages that may or

may not overlap (Gehrels 2000;

https://docs.google.com/

View?id=dcbpr8b2_7c3s6pxft)

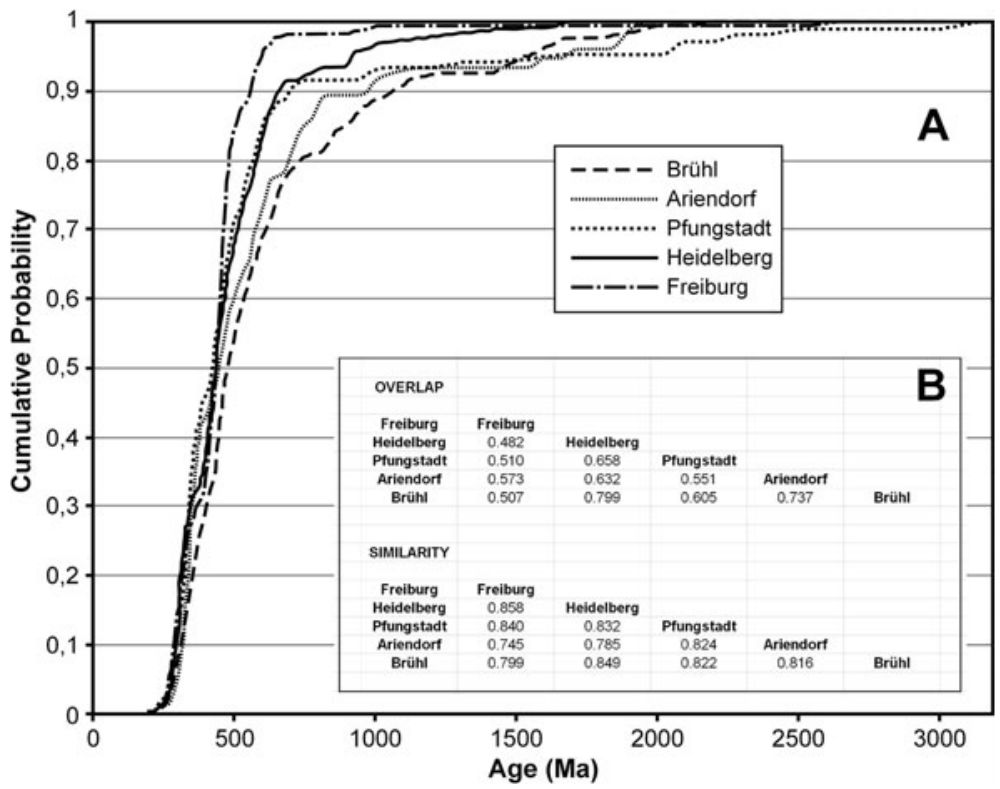

which age probabilities overlap (Gehrels 2000), is intermediate to high with values between 0.5 and 0.8 (Fig. 6b). High values of up to 1.0 indicate similar proportions of overlapping ages. From $\mathrm{S}$ to $\mathrm{N}$, between Freiburg and Ariendorf (Fig. 1), the relative weight of the main peaks at 440 and 350 Ma changes from a dominance of the older in the $\mathrm{S}$ to a dominance of the younger in the N. This probably reflects the basement geology traversed by the river with Caledonian age sources like the Black Forest and Vosges being tapped in the $\mathrm{S}$ and Variscan sources weighing in more strongly in the $\mathrm{N}$ (Figs. 1, 5). A return to the southern pattern is displayed by the northernmost sample from Brühl.

In view of the overall strong resemblance of the age distributions, it is useful to combine all data in one figure (Fig. 7) and discuss them in summary fashion. Most of the ages fall into distinct age groups between c. 1,100 and $300 \mathrm{Ma}$ (Fig. 7). A small number of individual ages cover the time between 2,500 and 1,400 Ma, with one Archean grain with an age of c. 3,100 Ma. The most prominent peak including $31 \%$ of ages is at c. $440 \mathrm{Ma}$ in the lowermost Silurian (Fig. 7; Gradstein and Ogg 2004). These ages can be linked to several very different sources. One potential source may be the Black Forest, and related complexes, where Variscan and Caledonian ages are equally abundant in late Devonian greywackes (Hegner et al. 2005). Another option is a derivation from the mid-German crystalline rise. In the Spessart and neighboring areas, Silurian ages such as c. 414 and 439 Ma (Lippolt 1986; Nasir et al. 1991) and c. 418 and $410 \mathrm{Ma}$ (Dombrowsky et al. 1995) were recorded (Sommermann 1993; Reischmann and Anthes 1996; Siebel et al. 1997). Alternatively, this age peak could be connected to the main parts of the Caledonian orogen now underlying northern Germany and being exposed in the British Isles and Scandinavia (McKerrow et al. 2000; Krawczyk et al. 2008). Micas of Caledonian age were dated in Keuper (Late Triassic) sediments in Germany by Paul et al. (2009) who postulate an origin of this detritus from the Caledonides of southern Norway. During the Keuper, episodic humid conditions led to the progradation of fluvial sediments, transported by large river systems, from Scandinavia southward into Central Europe and onwards toward Tethys (Wurster 1964; Köppen 1997; Paul et al. 2009). Therefore, a provenance from Baltica for the ages around $440 \mathrm{Ma}$ is also probable.

A further option is a derivation from Alpine sources as Schaltegger et al. (2003) found that Early to Late Ordovician source rocks occur in the northern Helvetic basement in the Central Alps. Similar rock associations are found in some external massifs like the Gotthard Massif and in the Austroalpine Silvretta Unit, developed during an evolution starting with oceanic and active margin magmatism in the Late Cambrian and ending with granitoid magmatism during an Ordovician to Silurian continent collision (e.g., Schaltegger et al. 2003). In the Penninic units, intracontinental rifting is documented at c. $500 \mathrm{Ma}$ and followed by granitoid magmatism between 480 and $450 \mathrm{Ma}$ (e.g., Guillot et al. 2002; Schaltegger et al. 2003). Stampfli et al. (2002) and von Raumer et al. (2002, 2003) assign different units of the Alpine basement to the Gondwana-derived Hun Superterrane, which are now spread over different Alpine nappes and basement units (Schaltegger et al. 2003). The Hun Superterrane includes all continental fragments, which were in lateral continuity with Avalonia along the Gondwana margin and accreted to Laurussia between the Late Devonian and Early 
Fig. 7 Summary U-Pb age (black) distributions for all five analyzed samples with grey probability curves and selected probability maxima. For comparison the upper part of the diagram displays the distribution of major orogenic events on Baltica, Amazonia,

West Africa, the Arabian-

Nubian-Shield (ANS) and northern Africa (modified from Linnemann et al. 2004; Bahlburg et al. 2010). A Alpine orogeny, $V$ Variscan orogeny, $C$ Caledonian orogeny

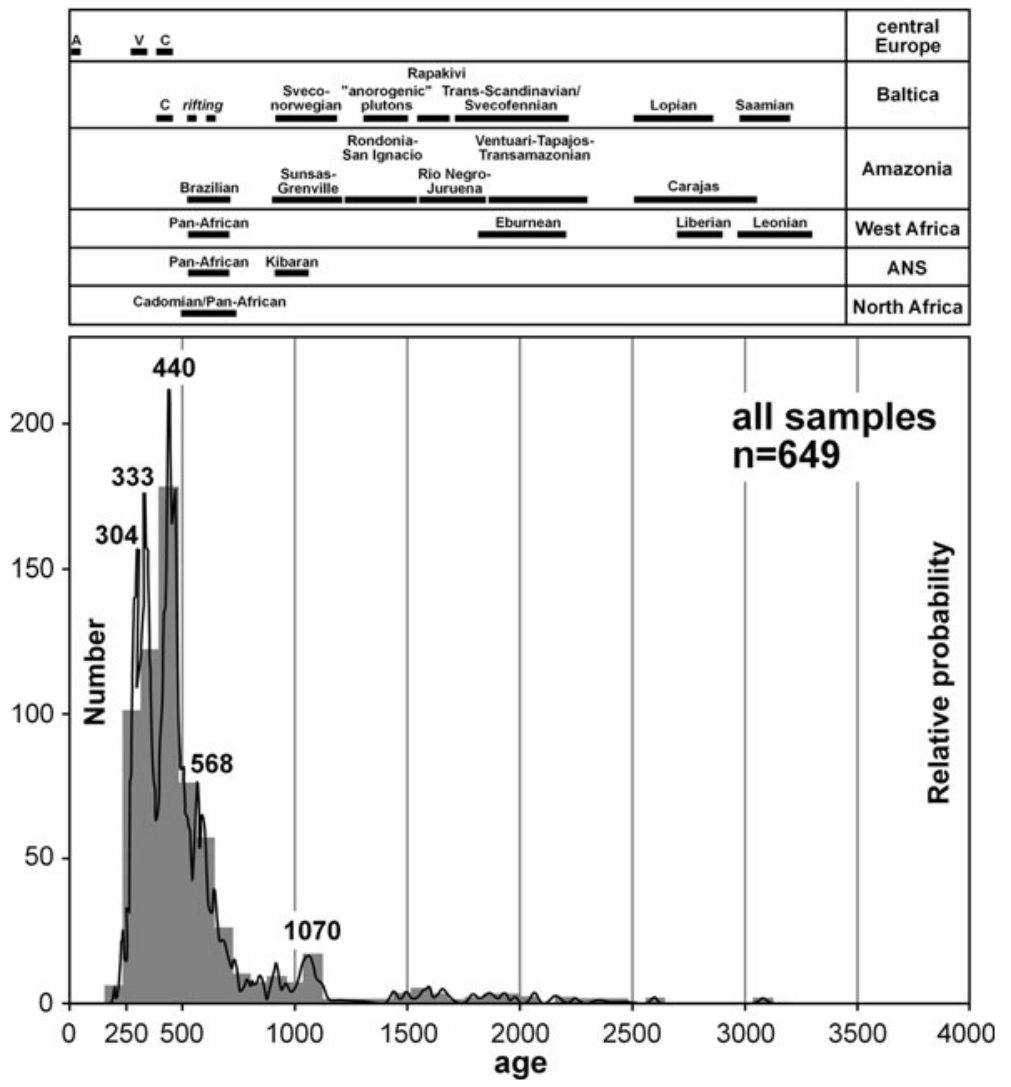

Carboniferous. The western part of the Hun Terrane coincides with the Armorican Terrane (van der Voo 1979; Tait et al. 1997; Stampfli et al. 2002) which also records widespread and predominantly felsic volcanism and intrusive activity connected to continental rifting (Floyd et al. 2000; Schätz et al. 2002; Martin et al. 2003; Kryza and Zalasiewicz 2008; Linnemann et al. 2008; Bahlburg et al. 2010).

The next prominent group with $28 \%$ of the total is between 385 and $280 \mathrm{Ma}$. The data distribution has maxima at 333 and 304 Ma (Fig. 7). This abundant group of ages represents the Hercynian (Variscan) orogeny in Europe (see summary in Kroner et al. 2008).

The third major age group between 775 and $545 \mathrm{Ma}$ (16\%) with a peak at c. $570 \mathrm{Ma}$ (Fig. 7) points to derivation of grains from rocks originating in the northern Gondwana Neoproterozoic Cadomian orogen (750 and $550 \mathrm{Ma}$; Murphy et al. 2000; Hirdes and Davis 2002; Nance et al. 2002; Linnemann et al. 2004; Gerdes and Zeh 2006; De Waele et al. 2008; Figs. 7, 8). Cadomian ages are absent on Baltica and Laurentia (e.g., Nance and Murphy 1994; Zeh et al. 2001; Linnemann et al. 2007).

Grains with ages older than c. $800 \mathrm{Ma}$ are not very abundant. This may be due to the fact that Mesoproterozoic and older rock units do not crop out on the central European continent. Furthermore, detrital zircon ages reflecting such associations are scarce also in most Mesozoic and Paleozoic siliciclastic sedimentary rocks in and overlying the Saxothuringian zone (Hofmann et al. 2009; Bahlburg et al. 2010). Meso- and Paleoproterozoic detrital zircon ages are more abundant in sedimentary rocks of the Rhenohercynian zone and here reflect an input from Baltica (Hofmann et al. 2009; Zeh and Gerdes 2010). A Baltica affinity would be characterized by ages between 900 and 1,800 Ma, which represent input from the Sveconorwegian orogen, the Transcandinavian Igneous Belt (c. 1.9-1.7 Ga), and the Sveconorwegian orogen (c. $1.0 \mathrm{Ga}$; Andersson et al. 2004; Zeh et al. 2001, and references therein). This input could potentially be reflected best in our northernmost sample from Brühl (Figs. 1, 4), which, however, shows only a slight increase in these ages. We have to conclude that our data do not permit a conclusive distinction between a northern Gondwana or Baltica provenance for these ages. Alternatively, the scarcity of Meso- and Paleoproterozoic detrital zircon ages in our samples may occur because we preferentially analyzed the rim of the zircon and hence the last growth stage of each zircon.

Implications of the detrital zircon age data

Garzanti et al. (2007) analyze the different types of orogenic belts and the mineralogical and geochronlogical provenance 
Fig. 8 Paleogeography of the Cadomian-Avalonian active margin and related major periGondwanan terranes at $\mathrm{c}$. 570 Ma (Bahlburg et al. 2010; modified from Linnemann et al. 2004). AM Armorican Massif, FMC French Massif Central, $S X Z$ Saxo-Thuringian zone (part of the Bohemian Massif), $T B U$ Teplá-Barrandian unit (part of the Bohemian Massif). Numbers in circles zircon ages from the cratons in $\mathrm{Ga}$. *1 from the compilation of Nance and Murphy (1994 and references therein), *2 from Avigad et al. (2003), Kolodner et al. (2006), Ali et al. (2009), Be'eri-Shlevin et al. (2009), *3 from Schneider Santos et al. (2000), *4 from the compilation of Zeh et al. (2001). Paleogeography of the Gondwanan continental plates after Unrug (1996)

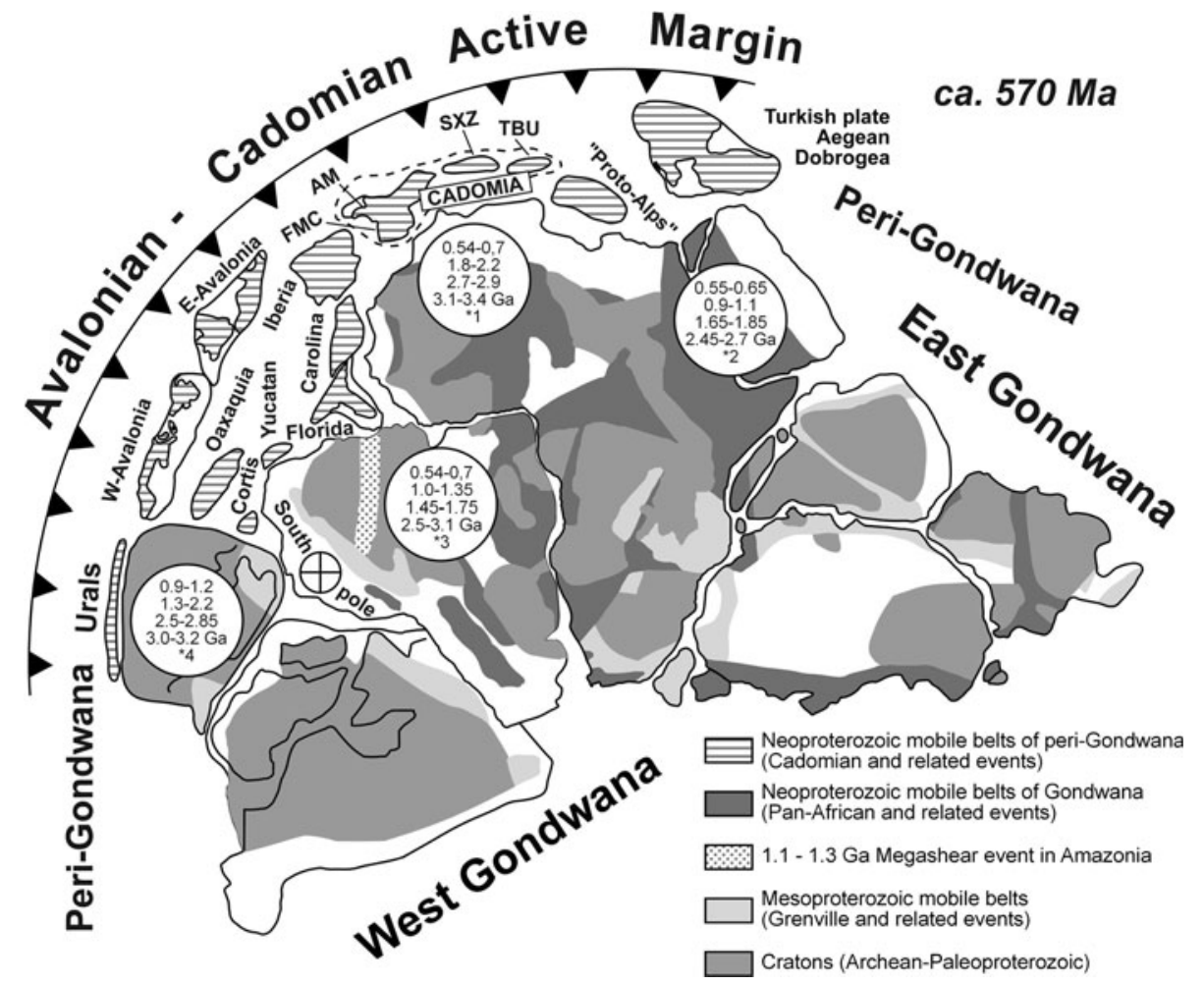

signatures they produce in sediments eroded from them. Collisional orogens can be divided into axial and external belts. Applied to the Alps, the axial belt contains the rapidly exhumed high-pressure metamorphic assemblages including those of the Penninic Domain which are the product of Cenozoic alpine neo-metamorphism. Instead, the external belts consist of basement and cover rocks. Sedimentary units deposited in foreland basins are derived from these rocks, as well as from erosion of early syn-collisional arc and subduction complexes and, in cases of rapid exhumation, dominantly from axial zone metamorphic units (Garzanti et al. 2007). These external basin fills may also contain significant amounts of detritus of older lithotectonic and paleometamorphic units having a pre-Alpine and potentially extra-orogenic tectonic provenance. Regarding the northern Alps, the external belt consists essentially of the Helvetic and Austroalpine domains.

Probably, the most remarkable feature of the detrital zircon age distribution in the studied Rhine River sediments from Freiburg to Bonn, and considering the geology of Europe, is the absence of ages younger than $200 \mathrm{Ma}$ (Figs. 4, 7). This includes the absence of any ages directly reflecting the Alpine orogeny between c. 100 and $35 \mathrm{Ma}$ (Froitzheim et al. 2008). If one would interpret these data as one would interpret similar data from, for example, Paleozoic sandstones and without detailed information on the regional geology, one would miss an entire collisional mountain belt, that is, the Alps.
One explanation rests in the absence of large-scale exposures of major batholiths in the Alps which would be prolific sources of zircons (e.g., Hawkesworth et al. 2009). Also, the Rhine River system today drains mainly the northern external belt of the Alps and only locally taps the axial belt which contains the main lithological bodies which could supply young zircons to the river system. There are only a few intrusive and metamorphic bodies exposed in the central Alps north of the Insubric Line, which are within reach of the drainage network of the Rhine River system, and the Hinterrhine in particular (e.g., Gebauer 1999; Bernet et al. 2004; Froitzheim et al. 1996; Liati et al. 2003 and references therein). The Hinterrhine taps the axial zone of the Penninic realm including the Lepontine Dome (Fig. 9). The Aare, Reuss, and Limat tributaries drain only the Helvetic external belt.

Considering the entire Rhine River system, indeed the Hinterrhine tributary represents only a very small portion of the entire system, but it is possible to deliver alpine zircons from the axial belt directly to the Rhine system. It is interesting to note in this context that detrital zircon age spectra obtained from modern sediments of the Indus and Ganges Rivers, which drain the axial zone of the Himalaya collisional orogen to a larger extent than the Rhine River does the Alps, contain a few percent of ages younger than $55 \mathrm{Ma}$, the time of the India-Eurasia collision (Campbell et al. 2005; Rino et al. 2008). The youngest U-Pb zircon age is $19.8 \pm 0.7 \mathrm{Ma}$ (Campbell et al. 2005). This 
Fig. 9 Map of the Alps and the adjacent foreland basins. External massifs: $A R$ Aiguilles Rouge, Mo Montblanc, Go Gotthard after Schlunegger (1999)

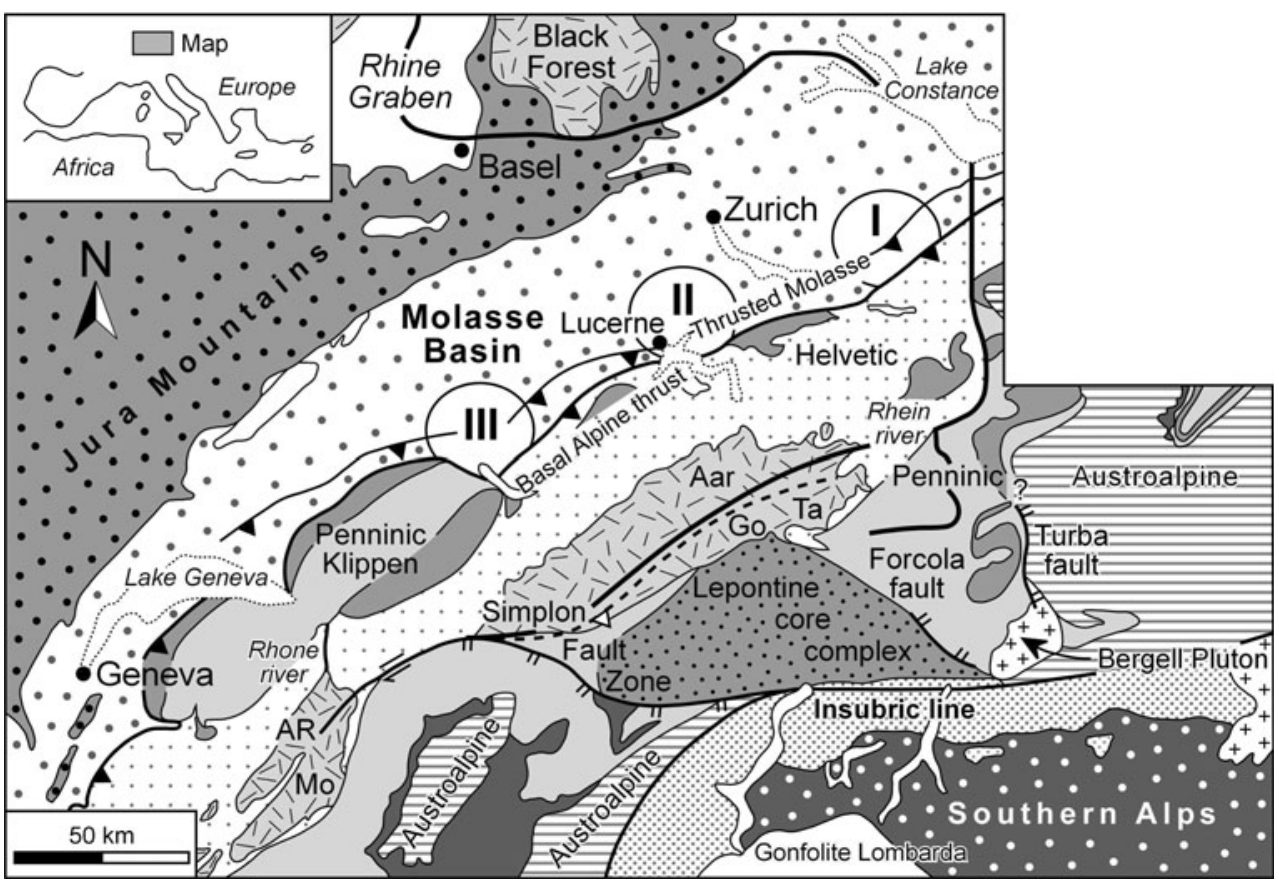

demonstrates that the denudation of such collisional orogens proceeds fast and deep enough to supply "young," syncollisional zircons from axial zones to draining river systems. Furthermore, for both the Himalaya and Alps cases, (U-Th)/He and fission track ages, respectively, show that detrital zircon grains, dated by the $\mathrm{U}-\mathrm{Pb}$ method, of river sediments were frequently polycyclic and were exhumed und supplied to river transport since c. $30 \mathrm{Ma}$ ago in both cases (Bernet et al. 2004; Campbell et al. 2005). We therefore do not exclude the possibility that the axial zone, at least theoretically, could have supplied young zircons to the river system via recycling pathways.

Quaternary sediments of the Cenozoic Lower Rhine embayment near Cologne contain zircons with $\mathrm{U}-\mathrm{Pb}$ ages between 42 and $26 \mathrm{Ma}$, which cannot be connected to parts of the Rhenish Massif or the Ardennes (Schärer et al. 2012). In view of the proximity of coeval centers of felsic volcanism including the Drachenfels trachyte of the Siebengebirge south of Cologne with an age of $25 \mathrm{Ma}$ (Wijbrans et al. 1995), it is much more likely that these young detrital zircons were derived locally and not from the Alps.

Detritus collected by the Alpine Rhine will today probably be trapped by Lake Constance. Calculations show, however, that Lake Constance would be filled with sediment within $22 \mathrm{ka}$ given present accumulation rates (Bernet et al. 2004). In terms of the temporal resolution considered here, which is on the order of several $100 \mathrm{ka}$, a feature like Lake Constance can be considered ephemeral. Consequently, we can generalize that in the Middle Pleistocene, Alpine detritus including zircons should have directly reached the Rhine River beyond Lake Constance.
Detritus supplied to the Aare tributary would reach and should also have reached the main Rhine system directly. We therefore conclude that in the Middle Pleistocene, input to the Rhine system of zircons younger than 200 Ma should be expected and should be registered at the sampled localities at least in small numbers. The fact that there are none in all studied samples along the Rhine River between Freiburg and Bonn, and bearing in mind the example from the Himalayas (Campbell et al. 2005), allows for the speculation that there may not have been such a supply to the Rhine River at this particular time. This, then, makes it very likely that the detritus representing the so-called A. spectrum in the Rhine River sediments in fact originates from sources outside the Alps, which prominently include the Black Forest and Vosges mountains, and the Molasse basin sediments.

\section{Further implications of the zircon data}

The youngest grain encountered in our samples has an age of $201 \pm 10$ Ma. The Middle Terrace Rhine River sands were deposited between 550 and $250 \mathrm{ka}$ (Boenigk and Frechen 2006). There is a time lag of c. $200 \mathrm{Ma}$ between the ages of zircon formation and deposition. Such lags are rather typical of rivers, which drain stable cratons and discharge at rifted margins like some east Australian rivers and the Yellow, Amazon, Orange, and Nile rivers (Sircombe 1999; Rino et al. 2008). The time lag is much smaller or virtually absent in rivers draining tectonically active mountain belts (Cawood et al. 2012) like the Indus, Ganges, Mekong, and Yangtze rivers which include zircon 
grains as young as $20 \mathrm{Ma}$ (Campbell et al. 2005). There the lag time between formation and deposition gets as low as $20 \mathrm{Ma}$, an order of magnitude smaller than in the case of the Rhine River.

Relatively short lag times on the order of a few million years to a few tens of millions of years seem to be typical also of strike-slip, collisional and subduction-related ancient, and modern settings where detritus may be transferred rapidly from source to sink (e.g., Augustsson et al. 2006; Bahlburg et al. 2011; Link et al. 2005; Rino et al. 2008; Jacobson et al. 2011).

Considering the tectonic setting of the Alps and the Rhine River, it therefore seems justified to expect at least small amounts of Alpine age zircons to be present in Pleistocene river sediments. If one treated the interpretation of our detrital zircon age data from the Rhine River similar to the approach taken in the interpretation of respective data on ancient sedimentary rocks in cases of a comparatively limited understanding of their tectonic setting (e.g., Cawood et al. 2003, 2007; Linnemann et al. 2004, 2007), one would probably conclude that the studied sediments were draining a relatively stable continental interior. This interpretation would miss an entire orogenic belt and would be misleading.

\section{Conclusion}

The heavy mineral assemblages of green hornblende, garnet, and epidote identified in Pleistocene Middle Terrace Rhine River deposits result either from the contribution of sediments derived from the Alps or can be connected to the Black Forest and the Vosges (e.g., Van Andel 1950; Hagedorn 2004; Hoselmann 2008). The appearance of pyroxene in the lower and middle Rhine area suggests a sediment origin from the Eifel volcanic field (Boenigk and Frechen 2006). The zircon age spectra of all samples from Pleistocene Middle Terrace sands and equivalents analyzed for this study are very similar. Most abundant are ages of Late Ordovician/Early Silurian and of Variscan age. Late Ordovician/Early Silurian ages point to Caledonian sources in Baltica or in the subsurface of northern Germany, to the mid-German crystalline rise, or to the Alps. Second-order maxima comprise Neoproterozoic U-Pb ages compatible with derivation from sources in northern Gondwana including the Cadomian orogen, the Arabian-Nubian Shield, and Baltica. Minor amounts of zircon grains of Grenvillian or Kibaran age (c. $1.0 \mathrm{Ga}$ ) were derived through recycling of intermittent sedimentary storage either from Baltica or northern Gondwana. The absence of detrital zircon $\mathrm{U}-\mathrm{Pb}$ ages younger than $200 \mathrm{Ma}$ and in particular the absence of ages reflecting the Alpine orogeny between 100 and $35 \mathrm{Ma}$, puts into question the generally made assumption of a direct delivery of Alpine detritus to the Rhine River system during at least some parts of the Pleistocene.

Finally, our study demonstrates that great care must be taken when detrital age spectra of ancient sandstones are interpreted. This applies particularly to cases like sedimentary units of allochthonous and exotic terranes where the detrital zircon record may be the only hard evidence of a deposit's tectonic setting or paleogeographic linkage.

Acknowledgments D. Ellwanger, Freiburg, supported our study with his expertise and valuable advice. We thank J. Berndt-Gerdes, Münster, for the assistance with the LA-ICP-MS and C. Gärtner, Münster, for the help with the scanning electron microscope and during the zircon data evaluation. She also commented on an earlier version of the manuscript. We acknowledge the help of T. Lauer during sampling in sand pits in the lower and middle Rhine area. For our study, we were given the opportunity to sample a number of drillcores. Access to the Pfungstadt-Hahn core was made possible by C. Hoselmann, Hessisches Landesamt für Umwelt, und Geologie (HLUG). We thank the Leibniz Institute für applied Geophysics (LIAG, Hannover) and the Geological Surveys of the federal states of Baden-Wüttemberg, Hessen, and Rheinland-Pfalz for access to the core of the Heidelberg UniNord locality of the Heidelberger drilling project. For the samples obtained from the Hartheim and Nambsheim cores, we thank the members of the Interegg II drilling project and the Landesamt für Geologie, Rohstoffe und Bergbau Baden-Württemberg. B. Fister, Münster, drafted most of the figures. We thank E. Garzanti, Milan, and an anonymous reviewer for their constructive reviews.

\section{References}

Ali KA, Stern RJ, Manton WI, Johnson PR, Mukherjee SK (2009) Neoproterozoic diamictite in the Eastern Desert of Egypt and Northern Saudi Arabia: evidence of $\sim 750$ Ma glaciation in the Arabian-Nubian Shield. Int J Earth Sci. doi:10.1007/s00531009-0427-3

Allen PA (1997) Earth surface processes. Blackwell Science, Boston, p 404

Andersson UB, Sjöström H, Högdahl K, Eklund O (2004) The Transscandinavian igneous belt, evolutionary models. Geol Surv Finl Spec Pap 37:104-112

Augustsson C, Münker C, Bahlburg H, Fanning CM (2006) Provenance of Provenance of late Palaeozoic metasediments of the SW South American Gondwana margin: a combined U-Pb and Hf-isotope study of single detrital zircons. J Geol Soc Lond 163:983-995

Avigad D, Kolodner K, McWilliams M, Persing H, Weissbrod T (2003) Origin of northern Gondwana Cambrian sandstone revealed by detrital zircon SHRIMP dating. Geology 31:227-230

Bahlburg H, Vervoort JD, DuFrane SA, Bock B, Augustsson C (2009) Timing of accretion and crustal recycling at accretionary orogens: insights learned from the western margin of South America. Earth Sci Rev 97:227-253

Bahlburg H, Vervoort JD, Du Frane SA (2010) Plate tectonic significance of Middle Cambrian and Ordovician siliciclastic rocks of the Bavarian Facies, Armorican Terranes Assemblage, Germany- $\mathrm{U}-\mathrm{Pb}$ and $\mathrm{Hf}$ isotope evidence from detrital zircons. Gondwana Res 17:223-235 
Bahlburg H, Vervoort JD, DuFrane SA, Carlotto V, Reimann C, Cárdenas J (2011) The U-Pb and Hf isotope evidence of detrital zircons of the Ordovician Ollantaytambo Formation, southern Peru, and the Ordovician provenance and paleogeography of southern Peru and northern Bolivia. J S Am Earth Sci 32:196-209

Be'eri-Shlevin Y, Katzir Y, Whitehouse MJ, Kleinhanns IC (2009) Contribution of pre Pan-African crust to formation of the Arabian-Nubian-Shield: new secondary ionization mass spectrometry U-Pb and O studies of zircon. Geology 37:899-902

Bernet M, Brandon MT, Garver JI, Molitor B (2004) Downstream changes of alpine zircon fission-track ages in the Rhône and Rhine Rivers. J Sediment Res 74:82-94

Blatt H (1978) Sediment dispersal from Vogelsberg basalt, Hessen, West Germany. Geol Rdsch 67:1009-1015

Boenigk W (1987) Petrographische Untersuchungen jungtertiärer und quartärer Sedimente am linken Oberrhein. Jahresberichte und Mitteilungen des Oberrheinischen Geologischen Vereines N.F. 69:357-394

Boenigk W, Frechen M (2006) The Pliocene and Quaternary fluvial archives of the Rhine system. Quart Sci Rev 25:547-550

Bogaard PVD, Schmincke H-U (1990) Die Entwicklungsgeschichte des Mittelrheinraumes und die Eruptionsgeschichte des OsteifelVulkanfeldes. In Schirmer W (ed) Rheingeschichte zwischen Mosel und Maas. deuqua-Führer, vol 1, pp 166-190

Campbell IH, Reiners PW, Allen CM, Nicolescu S, Upadhyay R (2005) $\mathrm{He}-\mathrm{Pb}$ double dating of detrital zircons from the Ganges and Indus rivers: implications for quantifying sediment recycling and provenance studies. Earth Planet Sci Lett 237:402-432

Cawood PA, Nemchin AA, Freeman M, Sircombe K (2003) Linking source and sedimentary basin: detrital zircon record of sediment flux along a modern river system and implications for provenance studies. Earth Planet Sci Lett 210:259-268

Cawood PA, Nemchin AA, Strachan R, Prave T, Krabbendam M (2007) Sedimentary basin and detrital zircon record along East Laurentia and Baltica during assembly and breakup of Rodinia. J Geol Soc Lond 164:257-275

Cawood PA, Hawkesworth C, Dhuime B (2012) Detrital zircon record and tectonic setting. Geology 40:875-878

Chang Z, Vervoort JD, Knaack C, McClelland WC (2006) U-Pb dating of zircon by LA-ICP-MS. Geochem Geophys Geosyst 7(5):1-14, Q05009. doi:10.1029/2005GC001100

Cohen KM, Gibbard P (2011) Global chronostratigraphical correlation table for the last 2.7 million years. Subcommission on Quaternary Stratigraphy (International Commission on Stratigraphy), Cambridge, England

Condie KC, Belousova E, Griffin WL, Sircombe KN (2009) Granitoid events in space and time: constraints from igneous and detrital zircon age spectra. Gondwana Res 15:228-242

De Waele B, Johnson SP, Pisarevsky SA (2008) Palaeoproterozoic to Neoproterozoic growth and evolution of the eastern Congo Craton: its role in the Rodinia puzzle. Precambr Res 160:127-141

Dombrowsky A, Henjes-Kunst R, Höhndorf A, Kröner A, Okrusch M, Richter P (1995) Orthogneisses in the Spessart crystalline complex, north-west Bavaria: Silurian granitoid magmatism at an active continental margin. Geol Rundsch 84:399-411

Floyd PA, Winchester JA, Seston R, Kryza R Crowly QG (2000) Review of geochemical variation in lower Palaeozoic metabasites from the NE Bohemian Massif: intracratonic rifting and plume-ridge interaction. In Franke W, Altherr R, Haak V, Oncken O (eds) Orogenic processes-quantification and modeling of the Variscan belt of central Europe. Geol Soc Lond Spec Publ 179:155-174

Froitzheim N, Schmid S, Frey M (1996) Mesozoic paleogeography and the timing of eclogite-facies metamorphism in the Alps: a working hypothesis. Eclogae Geol Helv 89:81-110
Froitzheim N, Plašienka D, Schuster R (2008) Alpine tectonics of the Alps and western Carpathians. In: McCann T (ed) The geology of Central Europe, vol 2. Mesozoic and Cenozoic, pp 1141-1232

Gabriel G, Ellwanger D, Hoselmann C, Weidenfeller M (2008) Preface: the Heidelberg Basin drilling project. Eiszeitalter und Gegenwart. Quart Sci J 57(3-4):253-260

Garzanti E, Andò S (2007a) Heavy mineral concentration in modern sands: implications for provenance interpretation. In: Mange MA, Wright DT (eds) Heavy minerals in use. Developments in sedimentology, vol 58, pp 517-545

Garzanti E, Andò S (2007b) Plate Tectonics and heavy mineral suites of modern sands. In: Mange, MA, Wright DT (eds) Heavy minerals in use. Developments in sedimentology, vol 58, pp 741-763

Garzanti E, Doglioni C, Vezzoli G, Andò S (2007) Orogenic belts and orogenic sediment provenance. J Geol 115:315-334

Garzanti E, Andò S, Vezzoli G (2009) Grain size dependence of sediment composition and environmental bias in provenance studies. Earth Planet Sci Lett 277:422-432

Gebauer D (1999) Alpine geochronology of the Central and Western Alps: new constraints for a complex geodynamic evolution. Schweizerische Mineralogische und Petrographische Mitteilungen 79:191-208

Gehrels GE (2000) Introduction to detrital zircon studies of Paleozoic and Triassic strata in western Nevada and northern California. In: Soreghan MJ, Gehrels GE (eds) Paleozoic and Triassic paleogeography and tectonics of western Nevada and northern California, vol 347. Geological Society of America Special Paper, pp 1-18

Gehrels G, Azor Pérez A (2011) Detrital zircon U-Pb geochronology: current methods and new opportunities. In: Busby C (ed) Tectonics of sedimentary basins: recent advances. Blackwell, Wiley

Gerdes A, Zeh A (2006) Combined U-Pb and Hf isotope LA-(MC-) ICP-MS analyses of detrital zircons; comparison with SHRIMP and new constraints for the provenance and age of an Armorican metasediment in central Germany. Earth Planet Sci Lett 249: 47-61

Gradstein FM, Ogg JG (2004) Geologic time scale 2004-why, how, and where next! Lethaia 37:175-181

Guillot F, Schaltegger U, Bertrand JM, Deloule E, Baudin T (2002) Ordovician magmatism in the Ruitor Massif (Internal W-Alps), $\mathrm{U}-\mathrm{Pb}$ on zircon of polycyclic crustal granites. Int J Earth Sci 91:964-978

Hagedorn E (2004) Sedimentpetrographie und Lithofazies der jungtertiären und quartären Sedimente im Oberrheingebiet. Dissertation, Köln

Handtke R (1980) Eiszeitalter 2. Die jüngste Erdgeschichte der Schweiz und ihrer Nachbargebiete. Ott. Verlag, p 703

Harley SL, Kelly NM (2007) Zircon. Tiny but timely. Elements 3:13-18

Hawkesworth C, Cawood P, Kemp T, Storey C, Dhuime B (2009) A matter of preservation. Science 323:49-50

Hegner E, Gruler M, Hann HP, Chen F, Güldenpfennig M (2005) Testing tectonic models with geochemical provenance parameters in greywacke. J Geol Soc Lond 162:87-96

Hincke E (2010) Deformierte Granite im Südschwarzwald als Indikatoren lokaler variszischer Deformationszonen. Dissertation, Hamburg

Hirdes W, Davis DW (2002) U-Pb geochronology of paleoproterozoic rocks in the southern part of the Kedougou-Kéniéba Inlier, Senegal, West Africa: evidence for diachronous accretionary development of the Eburnean Province. Precambr Res 118:83-99

Höck V, Marschallinger R, Topa D (1990) Granat-Biotit Geothermometrie in Metapeliten der Moravischen Zonein Österreich. Österr Beitr Met Goephys H.3:149-167 
Hofmann M, Voigt T, Linnemann U (2009) The sands of Pangea-U$\mathrm{Pb}-\mathrm{LA}-\mathrm{ICP}-\mathrm{MS}$ geochronology of detrital zircon grains; a case study of the Mesozoic of Central Europe. Schriftenreihe der Deutschen Gesellschaft für Geowissenschaften 63:140

Hoselmann C (2008) The Pliocene and Pleistocene fluvial evolution in the northern Upper Rhine Graben based on results of the research borehole at Viernheim (Hessen, Germany). Quat Sci J (Eiszeitalter und Gegenwart) 57:286-315

Hsü KJ, Giovanoli F, Kelts K (1984) Introduction: the Zubo 80 project. Contrib Sedimentol 13:1-4

Hubert JE (1962) A Zircon-Tourmaline-Rutile maturity index and the interdependence of the composition of heavy mineral assemblages with the gross composition and texture of sandstones. J Sed Petrol 32:440-450

Jackson S, Pearson NJ, Griffin WL, Belousova EA (2004) The application of laser ablation-inductively coupled plasma-mass spectrometry to in situ U-Pb zircon geochronology. Chem Geol 211:47-69

Jacobson CE, Grove M, Pedrick JN, Barth AP, Marsaglia KM, Gehrels GE, Nourse JA (2011) Late Cretaceous-early Cenozoic tectonic evolution of the southern California margin inferred from provenance of trench and forearc sediments. Geol Soc Am Bull 123:485-506

Kolodner K, Avigad D, McWilliams M, Wooden JL, Weissbrod T, Feinstein S (2006) Provenance of north Gondwana CambrianOrdovician sandstone: U-Pb SHRIMP dating of detrital zircons from Israel and Jordan. Geol Mag 143:367-391

Köppen A (1997) Faziesentwicklung in der frühen Obertrias Mitteleuropas-ein sequenzstratigraphischer Vergleich. Gaea heidelbergensis $2: 1-233$

Kosler J, Sylvester PJ (2003) Present trends and the future of zircon in geochronology; laser ablation ICPMS. In: Hanchar JM (ed) Zircon. Reviews in mineralogy and geochemistry, vol 53, pp 243-275

Krawczyk CM, McCann T, Cocks LR, England RW, McBride JH, Wybraniec S (2008) Caledonian tectonics. In: McCann T (ed) The geology of Central Europe, vol 1. Precambrian and palaeozoic, pp 303-381

Kroner U, Hahn T, Romer RL, Linnemann U (2007) The Variscan orogeny in the Saxo-Thuringian zone-heterogenous overprint of Cadomian/Paleozoic Peri-Gondwana Crust. In: Linnemann U, Nance RD, Kraft P, Zulauf G (eds) The evolution of the Rheic Ocean: from Avalonian-Cadomian active margin to Alleghenian-Variscan collision, vol 423. Geological Society of America Special Paper, pp 153-172

Kroner U, Mansy JL, Mazur S, Aleksandrowski P, Hann HP, Huckriede H, Lacquement F, Öamarche J, Ledru P, Pharaoh TC, Zedler H, Zeh A, Zulauf G (2008) Variscan tectonics. In: McCann $\mathrm{T}$ (ed) The geology of Central Europe, vol 1. Precambrian and palaeozoic, pp 303-381

Kryza R, Zalasiewicz JA (2008) Records of Precambrian-Early Palaeozoic volcanic and sedimentary processes in the Central European Variscides: a review of SHRIMP zircon data from the Kaczawa succession (Sudetes, SW Poland). Tectonophysics 461:60-71

Latouche L, Fabriès J, Guiraud M (1992) Retrogradeevolution in the CentralVosgesmountains (northeasternFrance): implications for the metamorphichistory of high-graderocks during the Variscanorogeny. Tectonophysics 205:387-407

Liati A, Gebauer D, Fanning MC (2003) The youngest basic oceanic magmatism in the Alps (Late Cretaceous; Chiavenna unit, Central Alps): geochronological constraints and geodynamic significance. Contrib Miner Petrol 146:144-158

Link PK, Fanning CM, Beranek LP (2005) Reliability and longitudinal change of detrital-zircon age spectra in the Snake River system, Idaho and Wyoming: an example of reproducing the bumpy barcode. Sed Geol 182:101-142
Linnemann U, McNaughton NJ, Romer RL, Gehmlich M, Drost K, Tonk C (2004) West African provenance for Saxo-Thuringia (Bohemian Massif): did Armorica ever leave pre-Pangean Gondwana? U/Pb-SHRIMP zircon evidence and the $\mathrm{Nd}$ isotopic record. Int J Earth Sci 93:683-705

Linnemann U, Gerdes A, Drost K, Buschmann B (2007) The continuum between Cadomian orogenesis and opening of the Rheic Ocean: constraints from LA-ICP-MS U-Pb zircon dating and analysis of plate-tectonic setting (Saxo-Thuringian zone, northeastern Bohemian Massif, Germany. In: Linnemann U, Nance RD, Kraft P, Zulauf G (eds) The evolution of the Rheic Ocean: from Avalonian-Cadomian active margin to Alleghenian-Variscan collision, vol 423. Geological Society of America Special Paper, pp 61-96

Linnemann U, Pereira F, Jeffries TE, Drost K, Gerdes A (2008) The Cadomian Orogeny and the opening of the Rheic Ocean: the diacrony of geotectonic processes constrained by LA-ICP-MS $\mathrm{U}-\mathrm{Pb}$ zircon dating (Ossa-Morena and Saxo-Thuringian Zones, Iberian and Bohemian Massifs). Tectonophysics 461:21-43

Lippolt HJ (1986) Nachweis altpaläozoischer Primäir-Alter (Rb-Sr) und karbonischer Abkühlugsalter (K-Ar) der Muskovit-BiotitGneise des Spessart und der Biotit-Gneise des Böllsteiner Odenwald. Geol Rundsch 75:569-583

Litt T, Schmincke HU, Frechen M Schlüchter C (2008) Quaternary. In: McCann T (ed) The geology of Central Europe, vol 2. Mesozoic and Cenozoic, pp 1287-1340

Mange MA, Maurer HFW (1992) Heavy minerals in color. Chapman \& Hall, London, $\mathrm{p} 147$

Martin U, Reischmann Th, Bahlburg H, Schätz M, Tait J, Bachtadse V (2003) The early palaeozoic break-up of northern Gondwana: sedimentology, physical volcanology and geochemistry of a submarine volcanic complex in the Bavarian facies association, Saxothuringian Basin, Germany. Gondwana Res 6:839-858

McKerrow WS, Mac Niocaill C, Dewey JF (2000) The Caledonian orogeny redefined. J Geol Soc Lond 157:1149-1154

Morton AC (1991) Geochemical studies of detrital heavy minerals and their application to provenance research. In: Morton AC, Todd SP, Haughton PDW (eds) Developments in sedimentary provenance studies. Geol Soc Lond, Spec Publ 57:31-45

Morton AC, Hallsworth CR (1999) Processes controlling the composition of heavy mineral assemblages in sandstones. Sed Geol 124:3-29

Morton AC, Hallsworth CR (2007) Stability of detrital heavy minerals during burial diagenesis. In: Mange M, Wright DK (eds) Heavy minerals in use. Developments in sedimentology, vol 58, pp 215-245

Murphy JB, Strachan RA, Nance RD, Parker KD, Fowler MB (2000) Proto-Avalonia: a 1.2-1.0 Ga tectonothermal event and constraints for the evolution of Rodinia. Geology 28:1071-1074

Muttoni G, Carcano C, Garzanti E, Ghielmi M, Piccin A, Pini R, Rogledi S, Sciunnach D (2003) Onset of major Pleistocene glaciations in the Alps. Geology 31:989-992

Nance RD, Murphy JB (1994) Contrasting basement isotopic signatures and the palinspastic restoration of peripheral orogens: example from the Neoproterozoic Avalonian-Cadomian belt. Geology 22:617-620

Nance RD, Murphy JB, Keppie JD (2002) A Cordilleran model for the evolution of Avalonia. Tectonophysics 352:1-21

Nance RD, Gutiérrez-Alonso G, Keppie JD, Linnemann U, Murphy JB, Quesada C, Strachan RA, Woodcock NH (2010) Evolution of the Rheic Ocean. Gondwana Res 17:189-192

Nasir S, Okrusch M, Kreuzer H, Lenz H, Höhndorf A (1991) Geochronology of the spessart crystalline complex, Mid-German crystalline rise. Mineral Petrol 44:39-55 
Nemchin AA, Cawood PA (2005) Discordance of the UePb system in detrital zircons: implication for provenance studies of sedimentary rocks. Sed Geol 182:143-162

Paul J, Wemmer K, Wetzel F (2009) Keuper (Late Triassic) sediments in Germany indicators of rapid uplift of Caledonian rocks in southern Norway. Nor J Geol 89:193-202

Pfiffner A (1992) Alpine orogeny. In: Blundell D (ed) The European geotraverse. University of London, London, pp 180-189

Reischmann T, Anthes G (1996) Geochronology of the mid-German crystalline rise west of the River Rhine. Geol Rundsch 85: 761-774

Rino S, Kon Y, Sato W, Maruyama S, Santosh M, Zhao D (2008) The Grenvillian and Pan-African orogens: World's largest orogenies through geologic time, and their implications on the origin of superplume. Gondwana Res 14:51-72

Robardet M (2003) The Armorica 'microplate': fact or fiction? Critical review of the concept and contradictory palaeobiogeographical data. Palaeogeogr Palaeoclimatol Palaeoecol 195:125-148

Robertson AHF (2007) Overview of tectonic settings related to the rifting and opening of Mesozoic ocean basins in the eastern Tethys; Oman, Himalayas and eastern Mediterranean regions. Geol Soc Spec Publ 282:325-388

Roetzel R, Kurzweil H (1968) Die Schwerminerale in niederöstereichischen Quarzsanden und ihre wirtschaftliche Bedeutung. Arch F Lagerst Forsch Geol B-A 7:199-216

Schaltegger U, Abrecht J, Corfu F (2003) The Ordovician orogeny in the Alpine basement: constraints from geochronology and geochemistry in the Aar Massif (Central Alps). Schweiz Mineral Petrogr Mitt 83:183-195

Schärer U, Berndt J, Scherer EE, Kooijman E, Deutsch A, Klostermann J (2012) Major geological cycles substantiated by U-Pb ages and $\varepsilon \mathrm{Hfi}$ of detrital zircon grains from the Lower Rhine Basin. Chem Geol 294-295:63-74

Schätz M, Reischmann T, Tait J, Bachtadse V, Bahlburg H, Martin U (2002) The Early Palaeozoic break-up of northern Gondwana, new palaeomagnetic and geochronological data from the Saxothuringian Basin, Germany. Int J Earth Sci 91:838-849

Schlunegger F (1999) Controls of surface erosion on the evolution of the Alps: constraints from the stratigraphies of the adjacent foreland basins. Int J Earth Sci 88:285-304

Schmid SM, Bernoulli D, Fügenschuh B, Matenco L, Schefer S, Schuster R, Tischler M, Ustaszewski K (2008) The AlpineCarpathian-Dinaridic orogenic system: correlation and evolution of tectonic units. Swiss J Geosci 101:139-183

Schneider Santos JO, Hartmann LA, Gaudette HE, Groves D, McNaughton NJ, Fletcher IR (2000) A new understanding of the provinces of the Amazon craton based on integration of field mapping and $\mathrm{U}-\mathrm{Pb}$ and $\mathrm{Sm}-\mathrm{Nd}$ geochronology. Gondwana Res 3:453-488

Siebel W, Raschka H, Irber W, Kreuzer H, Lenz KL, Höhndorf A, Wendt I (1997) Early Palaeozoic acid magmatism in the Saxothuringian Belt: new insights from a geochemical and isotopic study of orthogneisses and metavolcanic rocks from the Fichtelgebirge. J Petrol 38:203-230

Sindowsky KH (1936) Sediment und Fauna im Dogger des Breisgaus. Z Deut Geol Ges 88:380-398

Sircombe KN (1999) Tracing provenance through the isotope ages of littoral and sedimentary detrital zircon, eastern Australia. In: Bahlburg $\mathrm{H}$, Floyd PA (eds) Advanced techniques in provenance analysis of sedimentary rocks. Sedimentary geology, vol 124, pp 47-67

Sommermann AE (1993) Zirkonalter aus dem Granit der Bohrung Saar 1. Beih Eur J Mineral 5:145

Spiegel C, Siebel W, Frisch W, Zsolt B (2002) Nd and Sr isotopic ratios and trace element geochemistry of epidote from the Swiss Molasse basin as provenance indicators: implications for the reconstruction of the exhumation history of the Central Alps. Chem Geol 189:231-250
Stampfli GM, Hochard C (2009) Plate tectonics of the Alpine realm. Geol Soc Lond Spec Publ 327:89-111

Stampfli GM, von Raumer J, Borel GD (2002) Evolution of pre-Variscan terranes: from Gondwana to the Variscan collision. In: Martinez Catalan J, Hatcher RD, Arenas R, Diaz Garcia F (eds) VariscanAppalachian dynamics: the building of the late Paleozoic basement, vol 364. Geological Society of America Special Paper, pp 263-280

Tait JA, Bachtadse V, Franke W, Soffel HC (1997) Geodynamic evolution of the European Variscan fold belt: palaeomagnetic and geological constraints. Geol Rundsch 86:585-598

Trümpy R (1975) Penninic-Austroalpine boundary in the Swiss Alps: a presumed former continental margin and its problems. Am J Sci 275:209-238

Unrug R (1996) Geodynamic Map of Gondwana Supercontinent Assembly. Bureau de Recherches Géologiques et Minéres Orléans, Orléans

Van Andel TJH (1950) Provenance, transport and deposition of rhine sediments. Veenman and Zonen, Wageningen, p 129

Van der Voo R (1979) Paleozoic assembly of Pangea: a new plate tectonic model for the Taconic, Caledonian and Hercynian orogenies. Eos (Trans Am Geophys Union) 60:241

Vavra G (1990) On the kinematics of zircon growth and its petrogenetic significance: a cathodoluminescence study. Contrib Miner Petrol 106:90-99

Vavra G, Schmid R, Gebauer D (1999) Internal morphology, habit and $\mathrm{U}-\mathrm{Th}-\mathrm{Pb}$ microanalysis of amphibolite-to-granulite facies zircons: geochronology of the Ivrea Zone (Southern Alps). Contrib Miner Petrol 134:380-404

Villinger E (1998) Untersuchungen zur Flussgeschichte von Rhein und Donau in Südwestdeutschland. Jahresberichte und Mitteilungen des oberrheinischen geologischen Vereins N.F. 80:361-398

Von Eynatten H (2007) Heavy minerals in the Swiss Molasse basin: occurrence, frequency, chemistry and thermochronology. In: Mange MA, Wright DT (eds) Heavy minerals in use. Developments in Sedimentology, vol 58, pp 887-905

Von Hooshang A (1993) Petrographische Untersuchungen an Glimmerschiefern im Bereich Poigen, Fernitz und Langenlois (Moldanubikum). Jb Geol B-A 136:19-25

Von Raumer JF, Stampfli GM, Borel G, Bussy F (2002) Organization of pre-Variscan basement areas at the north-Gondwanan margin. Int J Earth Sci 91:35-52

Von Raumer JF, Stampfli GM, Bussy F (2003) Gondwana-derived microcontinents - the constituents of the Variscan and Alpine collisional orogens. Tectonophysics 365:7-22

Wiedenbeck M, Alle P, Corfu F, Griffin WL, Meier M, Oberli F, Von Quadt A, Roddick JC, Spiegel W (1995) Three natural zircon standards for $\mathrm{U}-\mathrm{Th}-\mathrm{Pb}, \mathrm{Lu}-\mathrm{Hf}$, trace element and REE analyses. Geostand Newslett 19:1-23

Wijbrans JR, Pringle MS, Koppers AAP, Scheveers R (1995) Argon geochronology of small samples using VULKAAN argon laserprobe. In: Proceedings of the Koninklijke Nederlandse Akademie Van Wetenschappen-biological chemical geological physical and medical sciences, vol 98, pp 185-218

Wurster P (1964) Geologie des Schilfsandsteins. Mitteilungen des Geologischen Staatsinstitutes Hamburg 13:1-144

Zeh A, Gerdes A (2010) Baltica and Gondwana-derived sediments in the Mid-German Crystalline Rise (Central Europe): implications for the closure of Rheic ocean. Gondwana Res 17:254-263

Zeh A, Brätz H, Millar IL, Williams IS (2001) A combined zircon SHRIMP and Sm-Nd isotope study of high-grade paragneisses from the mid-German crystalline rise: evidence for northern Gondwanan and Grenvillian provenance. J Geol Soc 158:983-994

Ziegler PA, Dèzes P (2006) Crustal evolution of Western and Central Europe. In: Gee DG, Stephenson RA (eds) European lithosphere dynamics, vol 32. Geological Society, London, Memoir, pp 43-56 